\title{
TBX21 Gene
}

National Cancer Institute

\section{Source}

National Cancer Institute. TBX21 Gene. NCI Thesaurus. Code C104248.

This gene is involved in the regulation of cytokine gene expression. 